\title{
QUANTIFICATION OF ROPINIROLE HYDROCHLORIDE IN API AND TABLETS BY NOVEL STABILITY-INDICATING RP-HPLC METHOD: IT'S VALIDATION AND FORCED DEGRADATION STUDIES
}

\author{
SADASHIVAIAH R., ROHITH G., SATHEESHA BABU B. K.*
}

Department of Pharmaceutics, Government College of Pharmacy, \#P Kalinga Rao Road, Subbaiah Circle, Bengaluru, Karnataka, India Email: bksatishbabu@gmail.com

Received: 25 Apr 2019, Revised and Accepted: 06 Aug 2019

\section{ABSTRACT}

Objective: A simple, economical, robust and stability-indicating reverse phase high performance liquid chromatography method was developed and validated for the quantification of ropinirole hydrochloride in API and tablets to achieve shorter retention time, to minimize human error by avoiding the use of buffers and weighing procedure and analyze more number of samples in shorter period of time with good accuracy.

Methods: The chromatographic conditions for separation of ropinirole hydrochloride was carried out using Gemini NX C18 column (15 cm x 4.6 $\mathrm{mm}), 5 \mu \mathrm{m}$ particle size with the mobile phase composing of methanol: acetonitrile $(70: 30 \mathrm{v} / \mathrm{v})$, delivered at flow rate $0.7 \mathrm{ml} / \mathrm{min}$ and $\mathrm{UV}$ detection wavelength at $250 \mathrm{~nm}$.

Results: The retention time was observed at $2.718 \mathrm{~min}$. The system suitability results were found to be within limits. The method was precise, with lower than $2 \% \mathrm{RSD}$ and the calibration curve was linear $\left(r^{2}=1\right)$ over a concentration range of $2.5-160 \mu \mathrm{g} / \mathrm{ml}$. The detection and quantification limit was found to be $0.045 \mu \mathrm{g} / \mathrm{ml}$ and $0.15 \mu \mathrm{g} / \mathrm{ml}$, respectively. Recovery of the drug was found between $100.09-100.19 \%$. The assay of ropinirole hydrochloride in ROPITOR ${ }^{\circledR}$ and ROPARK ${ }^{\circledR}$ tablets were found to be 100.4 and $103.60 \%$, respectively. The forced degradation studies were carried out to demonstrate the specificity of the method by exposing the API under conditions of hydrolysis, oxidation, thermal and photolytic as per ICH Q1A(R2) guidelines.

Conclusion: The low coefficient of variation and agreeable recovery confirmed that the newly developed method could be employed for routine analysis of ropinirole hydrochloride in API and tablets.

Keywords: Ropinirole hydrochloride, RP-HPLC, Stability-indicating, Validation, Precision

(C) 2019 The Authors. Published by Innovare Academic Sciences Pvt Ltd. This is an open access article under the CC BY license (http://creativecommons.org/licenses/by/4.0/) DOI: http://dx.doi.org/10.22159/ijap.2019v11i5.33759

\section{INTRODUCTION}

Ropinirole hydrochloride (RH) is the hydrochloride salt form of ropinirole, a non-ergot dopamine agonist with antiparkinson property [1], acting as a substitute for dopamine, ropinirole acts as a D2, D3 and D4 dopamine receptor agonist with more affinity for D2. It is weakly active at the 5-HT2, and $\alpha 2$ receptors [2]. Chemically RH is a 4-[2-(dipropylamino) ethyl]-1,3-dihydro-2H-indol-2-one, hydrochloride (fig. 1). The molecular formula and weight of $\mathrm{RH}$ are $\mathrm{C}_{16} \mathrm{H}_{24} \mathrm{~N}_{20}$. $\mathrm{HCl}$ and $296.84 \mathrm{~g} / \mathrm{mol}$, respectively. The pKa and water solubility was found to be 10.17 and $133 \mathrm{mg} / \mathrm{ml}$ [3]. It is available in both conventional and extended-release tablet dosage form in the dose range from $0.25 \mathrm{mg}$ up to $6 \mathrm{mg}$ [4]. It is prescribed for the treatment of parkinson's disease and restless legs syndrome [5].

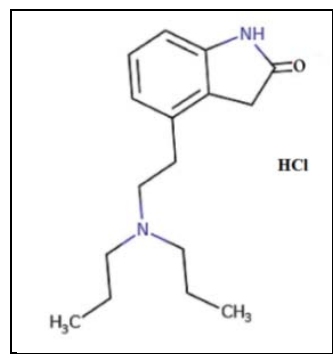

Fig. 1: Chemical structure of RH (Molecular formula: $\mathrm{C}_{16} \mathrm{H}_{24} \mathrm{~N}_{20}$. $\mathrm{HCl})$

Literature survey reveals that different spectroscopic methods have been reported for the estimation of RH using UV-Visible spectrophotometry [6], liquid chromatography (HPLC) with UV detector [7-9], PDA detector [10], ECD detector [11], high performance thin layer chromatography $[12,13]$ and LC-ESI-MS/MS coupled to tandem mass spectrometry with electrospray ionization [14]. Among them, reported HPLC analytical methods in the literature for quantifying RH in API and its formulation has either had longer retention time or have tedious analytical procedures or not developed stability-indicating analytical procedure.

The objective of the present study was to develop a new, simple, rapid, precise, accurate and stability-indicating RP-HPLC to quantify RH in API and tablet dosage form together with its validation study $[15,16]$. This work describes the validation parameters stated by the FDA [17] and ICH guidelines [18]. With the initiation of the ICH Q1A(R2) guidelines, requirements for the establishment of stability indicating methods have been ever more clearly mandated [19]. The guidelines explicitly require the conduct of forced degradation studies under a variety of conditions like hydrolysis (acid and alkaline), oxidation, photolytic and thermal, etc. and separation of drug from degradation products $[20,21]$.

\section{MATERIALS AND METHODS}

\section{Chemicals and reagents}

A working reference standard (100.07 \%) and API (100 \%) of RH was obtained as a gift sample from Alembic Pharmaceuticals Ltd., Vadodara, Gujarat, India. HPLC grade methanol and acetonitrile solvents were purchased from Merck Specialities Pvt. Ltd. Mumbai, India. ROPITOR ${ }^{\circledR} 0.5 \mathrm{mg}$ (Torrent Laboratories Pvt. Ltd.) and ROPARK $^{\circledR} 0.5 \mathrm{mg}$ (Sun Pharmaceuticals Industries Ltd.) tablets were procured from a local pharmacy. HPLC grade water was produced using a Millipore water purification system. AR grades of hydrochloric acid $(\mathrm{HCl})$, hydrogen peroxide $\left(\mathrm{H}_{2} \mathrm{O}_{2}\right)$ and sodium hydroxide $(\mathrm{NaOH})$ used were purchased from S D Fine Chem Limited, Bengaluru. Class-A glassware was used throughout the experiments.

\section{Instrumentation and chromatographic conditions}

The instrument used and optimized chromatographic conditions for the determination of RH is given in table 1. Other equipment used was 
UV-Visible spectrophotometer (LAMBDA ${ }^{\mathrm{m}} 365$, ParkinElmer Inc. USA), Analytical balance (Mettler Toledo, USA), Hot air oven and Digital ultrasonic water bath (Servewel instruments). A mixture of methanol: acetonitrile $(70: 30 \mathrm{v} / \mathrm{v})$ was used as a mobile phase which was filtered through $0.45 \mu \mathrm{m}$ finer porosity nylon membrane filter, degassed prior to use using a digital ultrasonic water bath.

\section{Table 1: Instrumentation and chromatographic conditions}

\begin{tabular}{ll}
\hline Parameter Instrument and optimized chromatographic conditions \\
\hline Instrument & High-performance liquid chromatography, Shimadzu-LC-20AD Prominence, Lab Solutions software was used for data \\
& acquisition and system suitability calculations. \\
Column & Phenomenex, Gemini NX C18 Column $(15 \mathrm{~cm}$ X $4.6 \mathrm{~mm}) 5 \mu \mathrm{m}$ particle size \\
Detector & UV Detector \\
Wavelength & $250 \mathrm{~nm}$ \\
Injection volume & $20 \mu \mathrm{l}$ \\
Flow rate & $0.7 \mathrm{ml} / \mathrm{min}$ \\
Mobile phase & Methanol: acetonitrile $(70: 30 \mathrm{v} / \mathrm{v})$ \\
Diluent & Mobile phase \\
Mode of operation & Isocratic elution \\
\hline
\end{tabular}

\section{Preparation of standard and sample solution}

The primary stock solution was prepared by dissolving API equivalent to $20 \mathrm{mg}$ in $100 \mathrm{ml}$ mobile phase, to get a concentration of $200 \mu \mathrm{g} / \mathrm{ml} .1 \mathrm{ml}$ of the primary stock solution was further diluted to $10 \mathrm{ml}$ with the mobile phase to get a final concentration of 20 $\mu \mathrm{g} / \mathrm{ml}$ (secondary stock solution). The absorbance of the secondary stock solution $(20 \mu \mathrm{g} / \mathrm{ml})$ was scanned in the range of 200 to 300 $\mathrm{nm}$ using a mobile phase as blank by UV-Visible spectrophotometer to select the detection wavelength. The sample solution was prepared by weighing twenty tablets from each product and their average weight was calculated, tablets were finely powdered. Tablet powder equivalent to $2 \mathrm{mg} \mathrm{RH}$ was weighed and transferred into a $100 \mathrm{ml}$ volumetric flask containing $75 \mathrm{ml}$ mobile phase, sonicated for $30 \mathrm{~min}$ with intermittent shaking to completely dissolve. Allowed to cool to room temperature and then made up the volume with the mobile phase to get a final sample concentration of $20 \mu \mathrm{g} / \mathrm{ml}$. The above secondary stock solution and sample solutions were filtered through $0.45 \mu \mathrm{m}$ nylon membrane (Millipore) syringe filter before injection.

\section{Analysis of RH in marketed tablets}

The developed method was used to estimate the total amount of drug present in commercially available tablets. The analysis was done by injecting API and sample drug solutions into the HPLC system $(n=3)$ and the peak area count was recorded. Determine the amount of drug present in each marketed tablet samples.

\section{Method validation}

The developed method has been validated as per the USP and ICH guidelines includes system suitability, specificity, precision (system repeatability, method repeatability and intermediate precision) linearity, range, LOD and LOQ, stability of analytical solution, accuracy and robustness $[17,18,23]$.

\section{System suitability}

The suitability of the system was tested by injecting the secondary stock solution into HPLC system as six replicates. The tailing factor for the RH peak from the first injection should be less than 2 and the column efficiency determined from the $\mathrm{RH}$ peak from the first injection should not be less than 2000 theoretical plates. The RSD for the mean peak area calculated from the six replicate injections of $\mathrm{RH}$ should be lower than $2 \%$ [23].

\section{Specificity and forced degradation studies}

Specificity consisted of interference of blank (mobile phase). It was carried out by injecting six replicates of the mobile phase into the HPLC system to check the interference of any peak at the main peak of the analyte [22].

Forced degradation study was carried to give information about the degradation behavior of analyte in the presence of its degradation products during stress conditions. The API was subjected to hydrolysis (acid and alkali), oxidative, thermal and photolytic stress conditions [20,21]. To assess the stress testing for acid hydrolysis, alkali hydrolysis, and oxidative studies by taking each $5 \mathrm{ml}$ of primary stock solution $(200 \mu \mathrm{g} / \mathrm{ml})$ was transferred into three $50 \mathrm{ml}$ volumetric flasks. Then the solution was mixed with $5 \mathrm{ml}$ of $0.1 \mathrm{~N}$ $\mathrm{HCl}, 5 \mathrm{ml}$ of $0.1 \mathrm{~N} \mathrm{NaOH}$ and $5 \mathrm{ml}$ of $3 \%$ hydrogen peroxide was added to each volumetric flask. The prepared solutions were heated at $80^{\circ} \mathrm{C}$ for $2 \mathrm{~h}$ in a boiling water bath, cooled to room temperature with intermittent shaking. These solutions were neutralized with an amount of acid or base equivalent to that of the previously added and then the volume was made up to the mark with mobile phase to get a concentration of the secondary stock solution. To assess the stress testing for thermal condition API was exposed to a temperature of $80^{\circ} \mathrm{C}$ for $48 \mathrm{~h}$ in a hot air oven. $20 \mathrm{mg}$ of API dried powder was weighed and transferred to a $100 \mathrm{ml}$ volumetric flask containing $75 \mathrm{ml}$ of mobile phase, dissolve and then volume is made up to the mark with the same, to get a concentration of $200 \mu \mathrm{g} / \mathrm{ml}, 1$ $\mathrm{ml}$ of the above solution was further diluted to $10 \mathrm{ml}$ with the mobile phase to get a final concentration of $20 \mu \mathrm{g} / \mathrm{ml}$. Photolytic stress testing the secondary stock solution $(20 \mu \mathrm{g} / \mathrm{ml})$ was exposed to UV light $(254 \mathrm{~nm})$ for $72 \mathrm{~h}$. Inject the resultant solution of all stress condition samples into the HPLC system, record the chromatograms to assess the degradation behavior of API during stress testing.

\section{Precision}

The precision of an analytical method is the closeness of agreement among individual test results when the method is applied repeatedly to multiple sampling of a homogenous sample. The precision of an analytical method is usually expressed in terms of RSD. In precision study system repeatability, method repeatability and intermediate precision have been carried out. The system and method repeatability were examined by analyzing API solution $(20 \mu \mathrm{g} / \mathrm{ml})$ in six replicates. $\%$ RSD of area counts of $\mathrm{RH}$ peak was calculated. Intermediate precision (Ruggedness) is carried out within the laboratory under different sets of conditions. Six replicates of API was injected into the HPLC system by different analysts, on different days (intradayrepeated for six replicates were injected at every $h$ up to $12 \mathrm{~h}$ in the same day and interday-repeated six replicates for $3 \mathrm{~d}$ ), on different instruments. \%RSD for each condition was calculated.

\section{Linearity, range}

Linearity and range were established from the standard stock solution, a series of solutions were prepared at concentration levels ranging from 2.5 to $160 \mu \mathrm{g} / \mathrm{ml}$ of the standard solution. The peak area responses of solutions at all levels in six replicates were measured. The area count versus concentration data was treated by linear regression analysis and the linearity of response to RH was determined by calculating the correlation coefficient (acceptance criterion of correlation coefficient shall not be less than 0.997).

\section{LOD and LOQ}

The LOD and LOQ were determined by visual evaluation by preparing the lowest dilution of API solution, injected into the HPLC system and the response obtained was recorded. 


\section{Stability of the analytical solution}

The stability of the analytical solution was performed by preparing $20 \mu \mathrm{g} / \mathrm{ml}$ concentrations of API and sample (tablets) solutions. Both the solutions were kept at room temperature and analyzed at time intervals of $0,24,48$ and $72 \mathrm{~h}$. Six replicates of the API and sample solutions were injected into the HPLC system. The corresponding area counts for API and sample solutions were measured. Calculated the cumulative \%RSD (acceptance criterion: cumulative \%RSD shall not be more than 2).

\section{Accuracy}

Accuracy study, known concentration of the sample $(10 \mu \mathrm{g} / \mathrm{ml})$ were taken separately into three set of nine volumetric flasks and spiked with known concentration of API at three different levels at $75 \%$ (Level 1), $100 \%$ (Level 2) and $125 \%$ (Level 3) of sample concentration in triplicates. The prepared solutions were analyzed by injecting six replicates of each set in each level into the HPLC system and calculate the percentage amount of API recovered in spiked sample and \%RSD in each level (acceptance criterion: \%recovery shall be in the range of 98-102 and \%RSD shall not be more than 2.0).

\section{Robustness}

The robustness of an analytical method is used to measure its capacity to remain unaffected by small but deliberate variations in methods parameters and provides an indication of its reliability during normal usage. The robustness of the developed method was determined by changing the instrumental conditions flow rate $( \pm 0.07 \mathrm{ml} / \mathrm{min})$, detection wavelength $( \pm 2 \mathrm{~nm})$ and composition of the mobile phase $( \pm 5 \mathrm{v} / \mathrm{v})$. System suitability parameters such as retention time, tailing factor, \% RSD of area counts and theoretical plates of the standard solution was checked at each variable condition. The amount of drug recovered for each instrumental condition was calculated. The overall $\%$ RSD between the data and the amount of drug recovered at each variable condition (acceptance criterion: system suitability should pass, overall \%RSD shall not be more than 2.0 and the amount of drug recovered should be less than $\pm 10 \%$ ).

\section{RESULTS AND DISCUSSION}

\section{HPLC method development and finalization}

The maximum absorbance ( $\lambda \max$ ) of $\mathrm{RH}$ was found to be $250 \mathrm{~nm}$ in mobile phase using UV-Visible spectrophotometer. The spectrum is shown in fig. 2. This wavelength was chosen for the detection of RH. Several researchers earlier reported HPLC analytical methods for estimation of ropinirole hydrochloride in bulk and its pharmaceutical dosage form by varying the mobile phase composition, flow rate and stationary phase (column) to elute the RH. The RP-HPLC analytical method developed consists of a mobile phase phosphate buffer $(\mathrm{pH} 6)$ and acetonitrile $(50: 50 \mathrm{v} / \mathrm{v})$, at a flow rate $0.5 \mathrm{ml} / \mathrm{min}$ stationary phase using C18 column 250 x $4.6 \mathrm{~mm}, 5$ $\mu \mathrm{m}$ particle size in isocratic mode and the total run time was $15 \mathrm{~min}$ achieved the retention time of $4.867 \mathrm{~min}$ [8]. RP-HPLC method developed with mobile phase comprising of acetate buffer $(0.05 \mathrm{~mol}$ glacial acetic acid, $\mathrm{pH} 3$ ):acetonitrile in the ratio of 50:50 v/v, at a flow rate $1 \mathrm{ml} / \mathrm{min}$ using the column C18 Hypersil BDS (250 x 4.6 $\mathrm{mm}, 5 \mu \mathrm{m}$ ) at $250 \mathrm{~nm}$, the analyte elutes at retention time of 4.037 min and running time is $14 \mathrm{~min}$ [7]. For the determination of impurities present in ropinirole tablets, the following HPLC analytical method was developed with retention time $26.80 \mathrm{~min}$. Two sets of mobile phases were employed, A (mixture of potassium dihydrogen phosphate buffer $(19.6 \mathrm{mmol})$ :acetonitrile $(98: 2 \mathrm{v} / \mathrm{v})$, adjust $\mathrm{pH} 7$ using triethylamine) and B (acetonitrile) for enhancing the peak resolution. The flow rate was maintained during the analysis was $1 \mathrm{ml} / \mathrm{min}$, the stationary phase used was Kromasil C8 $(250 \times 4.6 \mathrm{~mm}, 5 \mu \mathrm{m})$. The detector adopted was DAD detector and the mode of operation was in low-pressure gradient [10]. Another analytical method by RP-HPLC was developed to estimate simultaneously by ropinirole hydrochloride and its base by using a mobile phase acetonitrile: phosphate buffer $(55: 45 \mathrm{v} / \mathrm{v})$ of $\mathrm{pH} 6$ adjusted by adding $0.3 \%$ triethanolamine solution. The flow rate was $1 \mathrm{ml} / \mathrm{min}$. The stationary phase was Kromasil C18 (250 x $4 \mathrm{~mm})$ to achieve retention time for ropinirole hydrochloride and its base ropinirole was 7.70 and 5.04 min, respectively [9]. Further one more method was developed for RH were in an ECD detector was adopted. The mobile phase comprises of methanol: 50 mmol sodium dihydrogen phosphate $(10: 90 \mathrm{v} / \mathrm{v})$, and its $\mathrm{pH}$ was adjusted with diethylamine to 4.5 , the shorter stationary phase was Chromolith $\mathrm{RP}-18 \mathrm{e}(100 \times 4.6 \mathrm{~mm})$ to achieve $2.38 \mathrm{~min}$ as retention time and flow rate maintained was $2 \mathrm{ml} / \mathrm{min}$ [11]. To summarize the results with respect to the retention time and composition of the mobile phase from the above methods, retention time varies from $3.987 \mathrm{~min}$ to $26.80 \mathrm{~min}$ and with a shorter column length and high flow rate retention time was $2.85 \mathrm{~min}$. Suggested that the developed methods were not economical since consumption of the mobile phase was directly proportional to retention time and as retention time was more in the above methods also lead less turnout of the samples makes these methods were not economical. The preparation of various mobile phases which were used in the above available methods includes weighing and use of buffers for adjustment of $\mathrm{pH}$ contributes to the inclusion of errors during the mobile phase preparation. The objectives of the present study were to develop RPHPLC method to achieve shorter retention time, more turnout of the sample, less utilization of mobile phase and error-free procedure adopted to achieve economical method. The chromatographic method was developed by several trials were taken in order to finalize the chromatographic conditions. Various mobile phase composition with different $\mathrm{pH}$ was tried to elute the drug. The short retention time with a sharp peak of the analyte was dependent on the percentage of methanol and acetonitrile. Finally, the novel method was developed to quantitative estimation of RH in API and tablets consists of mobile phase methanol: acetonitrile $(70: 30 \mathrm{v} / \mathrm{v})$ with Phenomenex, Gemini NX, C18 column (15 cm x $4.6 \mathrm{~mm}, 5 \mu \mathrm{m}$ ) stationary phase, at a flow rate of $0.7 \mathrm{ml} / \mathrm{min}$ with a short runtime of $7 \mathrm{~min}$. The retention time was found to be $2.718 \mathrm{~min}$ and this abovedeveloped method yields satisfactory separation, stable baseline and sharp symmetrical peak with satisfactory system suitability results. A typical chromatogram of $\mathrm{RH}$ and placebo obtained by using the above mentioned mobile phase is illustrated in fig. 3 and 4 , respectively.

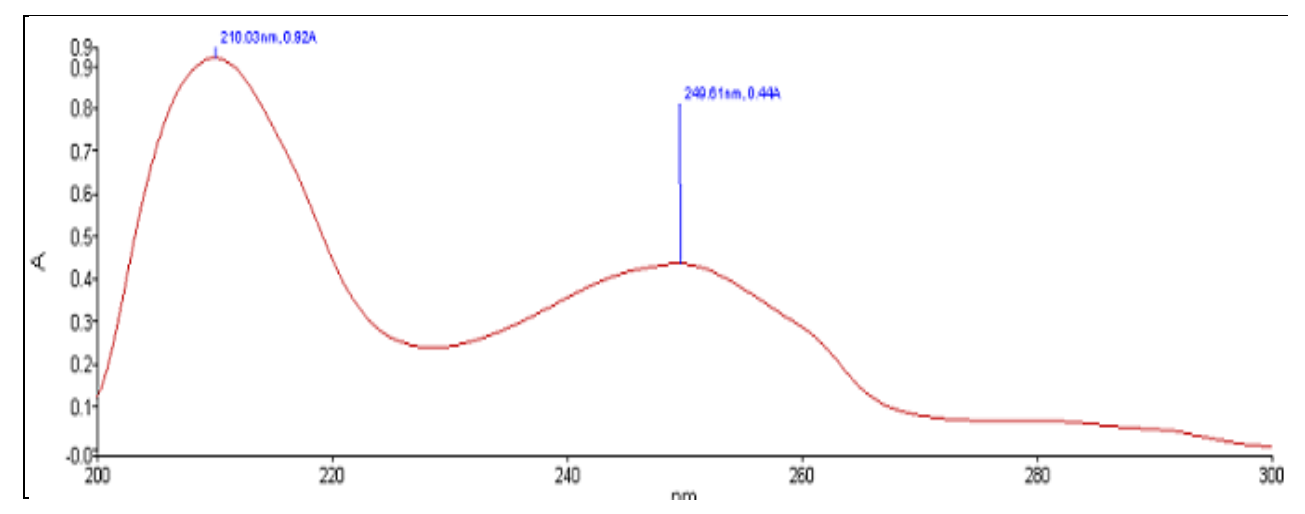

Fig. 2: UV-Visible spectra of RH in mobile phase $(30 \mu \mathrm{g} / \mathrm{ml})$, $\mathrm{x}$-axis=Wavelength ( $\mathrm{nm}$ ) and $\mathrm{y}$-axis=Absorbance 


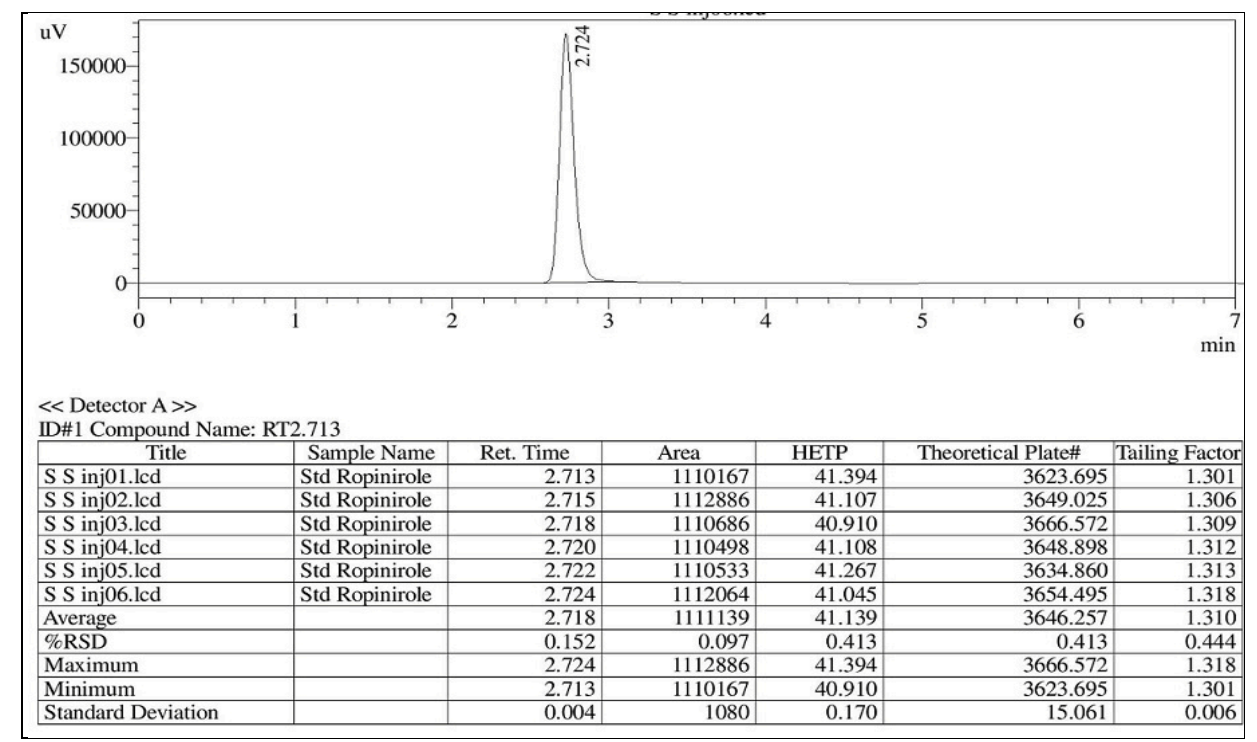

Fig. 3: HPLC Chromatogram and system suitability of RH at $250 \mathrm{~nm}(30 \mu \mathrm{g} / \mathrm{ml})$

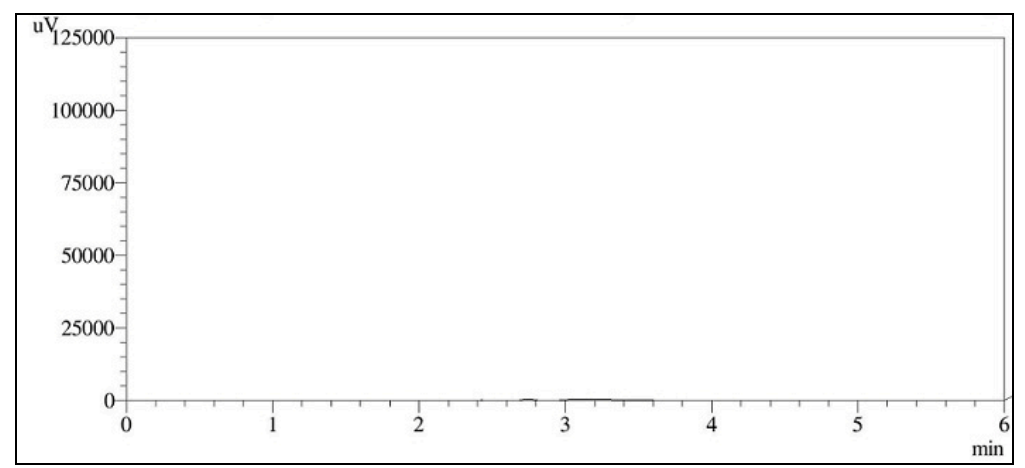

Fig. 4: HPLC Chromatogram of placebo at $250 \mathrm{~nm}$

\section{Analysis of RH in marketed tablets}

The amount of RH present in each product of ROPITOR ${ }^{\circledR}$ and ROPARK $^{\circledR}$ marketed tablets were found to be $0.502 \mathrm{mg}$ and 0.518 $\mathrm{mg}$, respectively. This is equivalent to 100.4 to 103.6 percent of the label claim. The determined \%assay of RH in both the tablets were found within the USP acceptance limits (90-110\%). The results show that there was no interference of excipients and impurities was observed in samples for the developed method.

\section{Method validation}

During the method validation study, known concentration of the standard solution was injected on different days. Using the LC solution software, retention time, theoretical plates and tailing factor for RH peak was recorded. \%RSD for six replicates was calculated. The retention time, theoretical plates $(\mathrm{N})$ and tailing factor for the RH from the API were found to be $2.718 \mathrm{~min}, 3646.257$ and 1.310, respectively. The RSD for the mean peak area count calculated from the six replicates was found to be $0.097 \%$. This indicates that the method is suitable. The above three system suitability parameters were met during the course of entire validation.

\section{Specificity and forced degradation studies}

The result of the specificity study indicates that there are not any coeluting peaks from the blank (mobile phase) at the retention time of the analyte proved the specificity of the developed method. In forced degradation studies the RH was found to be degrading in acidic, alkaline and oxidative stress conditions. The RH solution heated with $0.1 \mathrm{~N} \mathrm{HCl}$ at $80{ }^{\circ} \mathrm{C}$ for $2 \mathrm{~h}$ showed $1.50 \%$ degradation. Degradation peaks in acidic stress condition were observed at 3.63 . 3.96 and $6.66 \mathrm{~min}$. The RH solution heated with $0.1 \mathrm{~N} \mathrm{NaOH}$ at $80^{\circ} \mathrm{C}$ for $2 \mathrm{~h}$ showed $3.60 \%$ degradation. The degradation peaks in alkaline stress condition were observed at 4.12 and $4.48 \mathrm{~min}$. The $\mathrm{RH}$ solution in oxidative stress condition $\left(3 \% \mathrm{H}_{2} \mathrm{O}_{2}\right.$ to heat at $80{ }^{\circ} \mathrm{C}$ for $2 \mathrm{~h}$ ) was observed $3.2 \%$ degradation. The degradation peaks in oxidative stress condition were observed at 3.66 and $4.13 \mathrm{~min}$. During thermal degradation (exposed to $80{ }^{\circ} \mathrm{C}$ for $48 \mathrm{~h}$ ) and photo degradation (exposed to UV light for $72 \mathrm{~h}$ ), the chromatogram did not show the appearance of any degradation peak. Typical chromatograms obtained for RH under different conditions are shown in fig. 5. From the forced degradation study, it can be concluded that $\mathrm{RH}$ peak obtained by analysis of API in all the stress condition was homogenous, pure and unchanged by the presence of its degradation products, confirming the stability indicating nature of the method. Hence, the developed method is able to quantify RH in the presence of its degradation products.

\section{Precision}

The HPLC system and developed method have an acceptable level of precision. The system and method repeatability were found to be precise as the \%RSD of peak area counts for six replicates was found to be 0.349 and 0.532 , respectively. In intermediate precision, the individual and overall \%RSD under the different analytical procedure and laboratory conditions were found to be less than 2 . The results reveal that the newly developed method was rugged.

The precision data are tabulated in table 2 . 


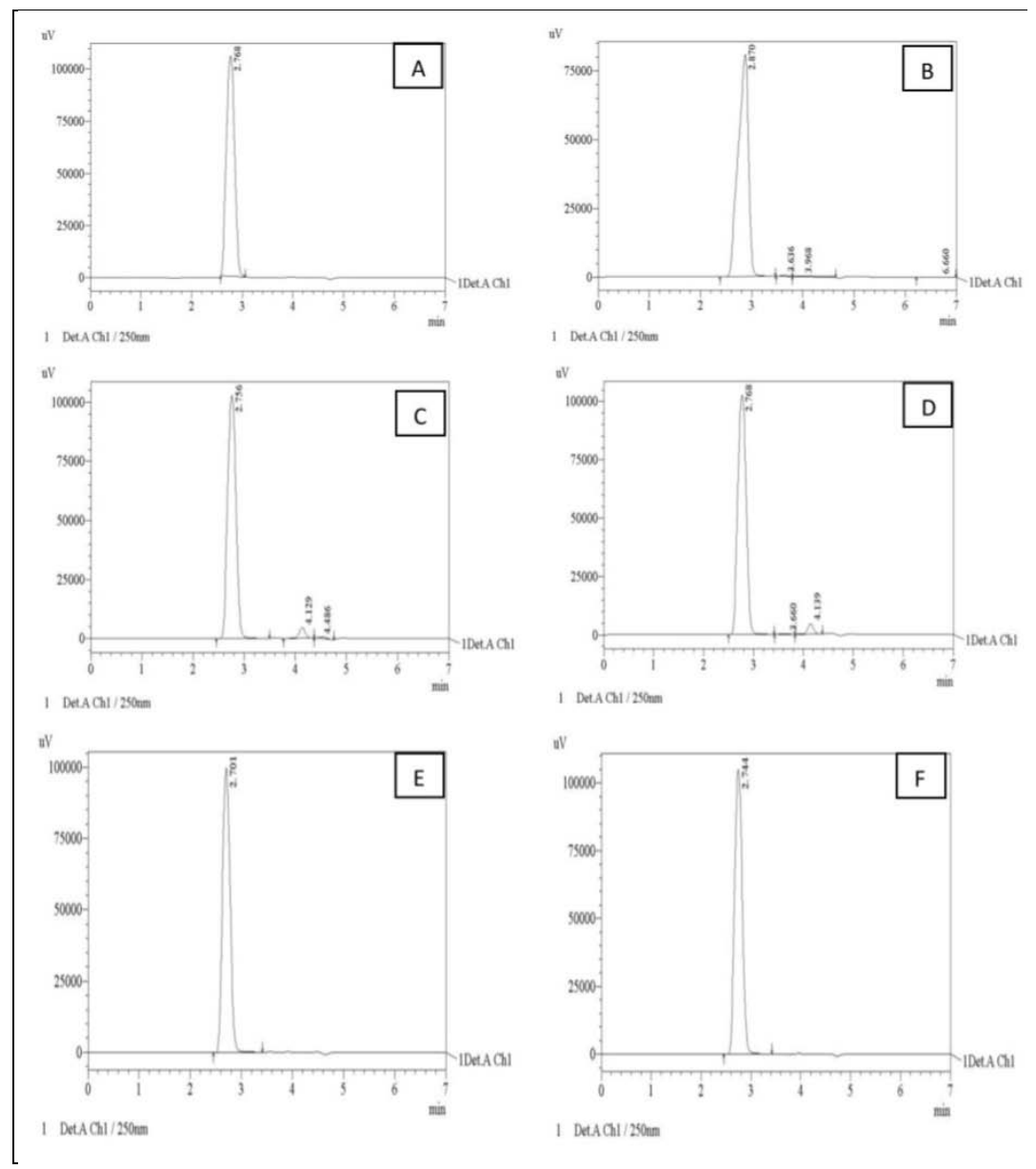

Fig. 5: HPLC Chromatograms showing forced degradation studies of $\mathrm{RH}$ under various stress conditions, $x$-axis=min and $y$-axis=peak area count (mV). Chromatograms showing API (A), acid degradation (B), alkaline degradation (C), oxidative degradation (D), thermal degradation (E) and photolytic degradation (F) studies

Table 2: Results of precision studies

\begin{tabular}{|c|c|c|c|c|c|c|c|c|c|c|}
\hline \multirow[t]{3}{*}{ Replicates } & \multirow{3}{*}{$\begin{array}{l}\begin{array}{l}\text { System } \\
\text { repeatability }\end{array} \\
\text { Peak Area }\end{array}$} & \multirow{3}{*}{$\begin{array}{l}\begin{array}{l}\text { Method } \\
\text { repeatability }\end{array} \\
\text { Peak area }\end{array}$} & \multicolumn{8}{|c|}{ Intermediate precision } \\
\hline & & & \multicolumn{2}{|l|}{ Intraday } & \multicolumn{2}{|c|}{ Interday } & \multirow{2}{*}{$\begin{array}{l}\text { Analyst } \\
1 \\
\text { Peak } \\
\text { area }\end{array}$} & \multirow{2}{*}{$\begin{array}{l}\text { Analyst } \\
2^{*} \\
\text { Peak } \\
\text { area }\end{array}$} & \multirow{2}{*}{$\begin{array}{l}\text { Instrument } \\
1 \\
\text { Peak area }\end{array}$} & \multirow{2}{*}{$\begin{array}{l}\text { Instrument } \\
2^{*} \\
\text { Peak area }\end{array}$} \\
\hline & & & $\begin{array}{l}\text { Time } \\
\text { interval } \\
\text { (in h) } \\
\end{array}$ & $\begin{array}{l}\text { Mean } \\
\text { peak } \\
\text { area } \\
\end{array}$ & Day & $\begin{array}{l}\text { Mean } \\
\text { peak } \\
\text { area } \\
\end{array}$ & & & & \\
\hline 1 & 1112707 & 1134189 & 1 & 1216773 & 1 & 1150322 & 1143874 & 1138905 & 1019233 & 1112886 \\
\hline 2 & 1121213 & 1137256 & 2 & 1219542 & 2 & 1170165 & 1158275 & 1142407 & 1017847 & 1110686 \\
\hline 3 & 1120612 & 1132983 & 3 & 1204308 & 3 & 1148159 & 1149481 & 1141323 & 1025641 & 1110498 \\
\hline 4 & 1119116 & 1137629 & 4 & 1204323 & & & 1154487 & 1138001 & 1016798 & 1110167 \\
\hline 5 & 1118148 & 1147987 & 5 & 1211827 & & & 1137829 & 1143322 & 1021178 & 1110533 \\
\hline \multirow[t]{2}{*}{6} & 1124416 & 1145244 & 6 & 1214152 & & & 1155630 & 1133875 & 1015161 & 1112064 \\
\hline & & & 12 & 1212006 & & & & & & \\
\hline Mean & 1119369 & 1139215 & & 1211847 & & 1156215 & 1149929 & 1139639 & 1019310 & 1111139 \\
\hline SD & 3908 & 6062 & & 5806 & & 12129.08 & 7826 & 3479 & 3721 & 1080.347 \\
\hline$\%$ RSD & 0.349 & 0.532 & & 0.479 & & 1.049 & 0.681 & 0.305 & 0.365 & 0.097 \\
\hline
\end{tabular}

*Results obtained in different analysts by a different instrument, SD stands for standard deviation of six replicates.

\section{Linearity, range}

The regression equation from peak area count versus concentration data (fig. 6) obtained $y=57411 x+4867$ and correlation coefficient $\left(r^{2}\right)$ was 1 , indicating that the response is linear over the specified range of $2.5-160 \mu \mathrm{g} / \mathrm{ml}$. The results are shown in table 3 .

\section{LOD, LOQ and stability of the analytical solution}

The LOD and LOQ for RH were found to be $0.045 \mu \mathrm{g} / \mathrm{ml}$ and 0.15 $\mu \mathrm{g} / \mathrm{ml}$, respectively. It reveals that the developed method was more sensitive [24]. The cumulative \%RSD of the API and sample solution was found to be 0.87 and 0.82 , respectively, at room temperature. The determined cumulative \%RSD of API and sample solution of RH was well within the limits of $2.0 \%$. It reveals that API and sample are stable in solution up to $72 \mathrm{~h}$ at room temperature.

\section{Accuracy}

Recovery studies of three samples in three concentration levels ranging from 75 to $125 \%$ were determined. The individual and overall percentage recovery and \%RSD of the API were found within 
the acceptance criteria, it was found that the percent recovery value of the API from the reanalyzed solution of the formulation was between 98 to 102 . This indicates that the method is accurate and also reveals that commonly used excipients and additives in the tablet formulation were not interfering in the developed method. The results are given in table 4 .

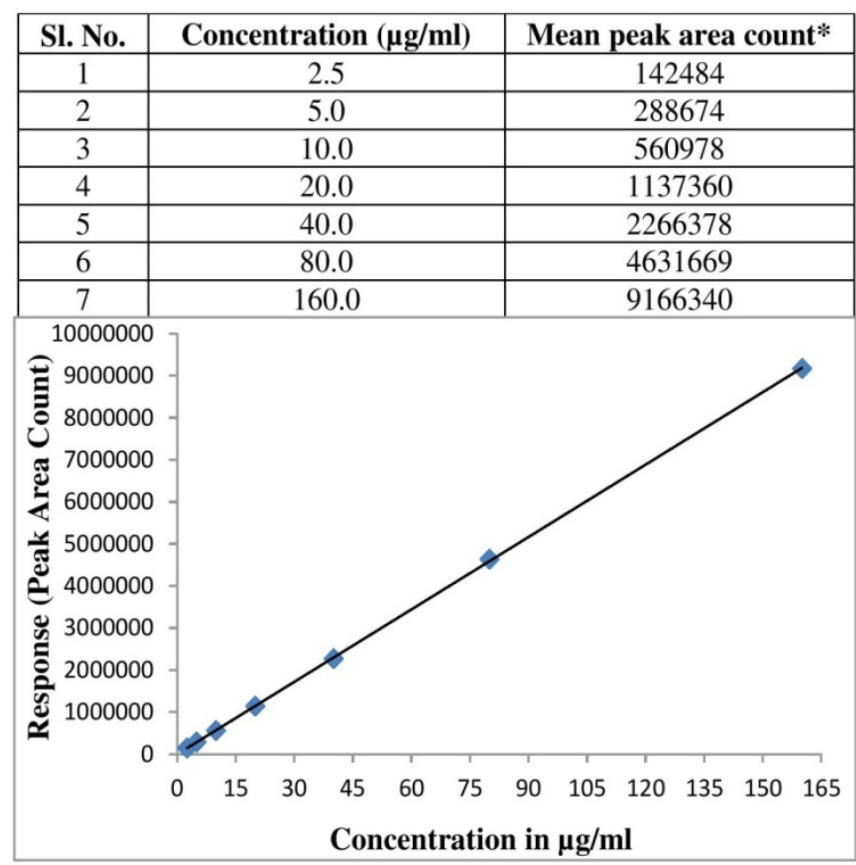

Fig. 6: Calibration curve of $\mathrm{RH}\left(\mathrm{y}=57411 \mathrm{x}+4867, r^{2}=1\right),\left({ }^{*} \mathrm{n}=6\right)$

Table 3: Summary of regression analysis of the calibration curve

\begin{tabular}{lll}
\hline Parameters & Results & Acceptance Criteria \\
\hline Linearity Range $(\mu \mathrm{g} / \mathrm{ml})$ & $2.5-160$ & - \\
Regression equation $(\mathrm{y}=\mathrm{mx}+\mathrm{c})$ & $\mathrm{y}=57411 \mathrm{x}+4867$ & - \\
Correlation co-efficient $\left(r^{2}\right)$ & 1.0 & Not less than 0.997 \\
Percentage curve fitting & $99.9 \%$ & Not less than $99 \%$ \\
Intercept $(c)$ & 4867 & - \\
Slope $(\mathrm{m})$ & 57411 & - \\
\hline
\end{tabular}

Table 4: Accuracy data

\begin{tabular}{|c|c|c|c|c|c|c|c|}
\hline $\begin{array}{l}\text { Level } \\
(\%) \\
\end{array}$ & $\begin{array}{l}\text { Sample conc. } \\
(\mu \mathrm{g} / \mathrm{ml})\end{array}$ & $\begin{array}{l}\text { Amt of std. added } \\
(\mu \mathrm{g} / \mathrm{ml})\end{array}$ & $\begin{array}{l}\text { Mean peak } \\
\text { area }\end{array}$ & $\begin{array}{l}\text { Amt of std. } \\
\text { recovered }(\mu \mathrm{g})\end{array}$ & $\begin{array}{l}\% \\
\text { recovery }\end{array}$ & $\begin{array}{l}\text { Average } \\
\% \text { recovery }\end{array}$ & $\begin{array}{l}\text { Mean } \\
\text { \%RSD } \\
\end{array}$ \\
\hline \multirow[t]{3}{*}{75} & 10 & 5 & 862928 & 5.000 & 100.01 & 100.17 & 0.470 \\
\hline & 10 & 5 & 865633 & 4.998 & 99.95 & & \\
\hline & 10 & 5 & 864490 & 5.025 & 100.55 & & \\
\hline \multirow[t]{3}{*}{100} & 10 & 10 & 1157061 & 10.113 & 101.13 & 100.19 & 0.531 \\
\hline & 10 & 10 & 1160680 & 10.760 & 99.76 & & \\
\hline & 10 & 10 & 1154523 & 10.069 & 100.69 & & \\
\hline \multirow[t]{3}{*}{125} & 10 & 15 & 1451613 & 14.934 & 99.56 & 100.09 & 0.135 \\
\hline & 10 & 15 & 1453342 & 15.264 & 100.76 & & \\
\hline & 10 & 15 & 1458129 & 14.993 & 99.95 & & \\
\hline
\end{tabular}

Six replicates of 3 observations $(n=3)$ in each level

Table 5: Robustness data

\begin{tabular}{|c|c|c|c|c|c|c|c|}
\hline \multirow[t]{2}{*}{ Parameters } & \multirow[t]{2}{*}{$\begin{array}{l}\text { Normal } \\
\text { condition* }\end{array}$} & \multicolumn{2}{|c|}{$\begin{array}{l}\text { Flow rate } \\
( \pm 10 \% \mathrm{ml} / \mathrm{min})\end{array}$} & \multicolumn{2}{|c|}{$\begin{array}{l}\text { Wavelength } \\
( \pm 2 \mathrm{~nm})\end{array}$} & \multicolumn{2}{|c|}{$\begin{array}{l}\text { Mobile phase } \\
( \pm 5 \mathrm{v} / \mathrm{v})\end{array}$} \\
\hline & & 0.63 & 0.77 & 248 & 252 & $65: 35$ & $75: 25$ \\
\hline Retention time (min) & 2.874 & 3.437 & 2.975 & 2.972 & 2.984 & 2.758 & 2.644 \\
\hline Tailing factor & 1.310 & 1.494 & 1.479 & 1.173 & 1.508 & 1.173 & 1.196 \\
\hline RSD $(\%)$ & 0.532 & 0.433 & 0.121 & 0.179 & 0.295 & 0.696 & 0.616 \\
\hline Theoretical plate(\#) & 3646 & 2897 & 3127 & 2975 & 3614 & 3162 & 3098 \\
\hline Amount of drug recovered (\%) & 102.55 & 106.98 & 95.86 & 98.83 & 98.20 & 95.71 & 97.84 \\
\hline
\end{tabular}

*Mobile phase: methanol: acetonitrile (70:30 v/v), column: Gemini NX C18-Phenomenex, detection wavelength: $250 \mathrm{~nm}$, flow rate: 0.7 ml/min and injection volume: $20 \mu \mathrm{l}$. 


\section{Robustness}

With all the deliberate varied chromatographic conditions (flow rate, wavelength of detection and composition of the mobile phase). The results obtained were well within the limit, which proves the robustness of the method. The results of robustness data are given in table 5 .

\section{CONCLUSION}

The present work, stability-indicating RP-HPLC method was developed for the quantitative estimation of RH in API and tablets is simple, rapid, economical, precise and accurate. The method has been validated and satisfactory results were found in all the tested validation parameters. The retention time was found to be 2.718 min due to this the method require less time, the consumption of the mobile phase is less. Preparation of the mobile phase involves no weighing procedures and use of buffers thereby reduces the human and instrumental error and increase the efficacy of the method as compared with the earlier reported HPLC-UV/DAD/ECD methods. The API and sample solution was stable up to $72 \mathrm{~h}$ at room temperature. The results of the stress testing reveal that the method is specific and there is no other co-eluting peak with the RH main peak. Hence, the developed method can be conveniently used for determining the quality control of RH in API and tablets.

\section{Acknowledgment}

The authors are thankful to M/s Alembic Pharmaceuticals Ltd, Vadodara, Gujarat, India for providing gift samples of working reference standard and API of RH with a certificate of analysis.

\section{AUTHORS CONTRIBUTIONS}

The first author conducted the experimental studies, data acquisition, data analysis, manuscript preparation and editing and the second author helped in manuscript preparation and editing. The third author designed and supervised the experimental work, data acquisition, data analysis, preparation of manuscript and critically reviewed the manuscript for final approval.

\section{CONFLICTS OF INTERESTS}

Declared none

\section{REFERENCES}

1. Sweetman SC. Martindale: the complete drug reference. $36^{\text {th }}$ ed. London: Pharmaceutical Press; 2009.

2. DeMaagd G, Philip A. Introduction to the pharmacotherapy of parkinson's disease, with a focus on the use of dopaminergic agents. Pharm Ther 2015;40:590-600.

3. Moursi NM, Elshafeey AH, Hamza MY, Elhadidy RM. Characterization and bioavailability study of ropinirole hydrochloride intranasal mucoadhesive thermoreversible insitu gel. J Am Sci 2018;14:125-39.

4. Singh ND, Banga AK. Controlled delivery of ropinirole hydrochloride through skin using modulated iontophoresis and microneedles. J Drug Target 2013;21:354-66.

5. Zesiewicz TA, Chriscoe S, Jimenez T, Upward J, VanMeter S. A fixeddose, dose-response study of ropinirole prolonged release in early stage parkinson's disease. Neurodegener Dis Manag 2017;7:49-59.

6. Raghubabu K, Jagannadharao V, Ramu BK. Assay of ropinirole hydrochloride in pharmaceutical preparations by UV-visible spectrophotometry. Asian J Pharm Anal 2012;2:41-5.

7. Samala A, Sowmya M, Sasikala M, Chatlapelli K. Development and validation of RP-HPLC method for the estimation of ropinirole hydrochloride in tablet dosage forms. J Chem Pharm Res 2014;6:1178-82.

8. Sreekanth N, Rao B, Mukkanti K. RP-HPLC method development and validation of ropinirole hydrochloride in bulk and pharmaceutical dosage forms. Int J Pharm Pharm Sci 2009;1:186-92.

9. Fuster J, Negro S, Salama A, Fernandez Carballido A, Marcianes P, Boeva L, et al. HPLC-UV method development and validation for the quantification of ropinirole in new PLGA multiparticulate systems: microspheres and nanoparticles. Int J Pharm 2015;491:310-7.

10. Kakouris A, Samara V, Kalaskani A, Panderi I. Simultaneous determination of impurities in ropinirole tablets by an improved HPLC method coupled with diode array detection. Chromatographia 2014;77:447-57.

11. Hefnawy M, Al-Majed A, Mohammed M, Attia S, Rizk M, ElEryan RT. Development of a monolithic HPLC-ECD method for the determination of ropinirole $\mathrm{HCl}$ in mouse sera and dosage forms. Br J Pharm Res 2016;13:1-11.

12. Bari SB, Bakhshi AR, Jain PS, Surana SJ. Development and validation of stability-indicating tlc-densitometric determination of ropinirole hydrochloride in bulk and pharmaceutical dosage form. Pharm Anal Acta 2011;2:1-7.

13. Mustafa G, Ahuja A, Baboota S, Ali J. Box-behnken supported validation of stability-indicating high performance thin-layer chromatography method: an application in degradation kinetic profiling of ropinirole. Saudi Pharm J 2013;21:93-102.

14. Bharathi DV, Jagadeesh B, Kumar SS, Lakshmi RN, Hotha KK, Naidu A, et al. Highly sensitive method for the determination of ropinirole with a lower limit of quantitation of $3.45 \mathrm{pg} / \mathrm{ml}$ in human plasma by LC-ESI-MS/MS: application to a clinical pharmacokinetic study. Biomed Chromatogr 2009;23:557-62.

15. Sindhusri M, Swetha T, Ramadevi A, Kumar AA. A novel rapid RP-HPLC method development and validation for the quantitative estimation of balofloxacin in tablets. Int J Pharm Pharm Sci 2014;7:319-22.

16. Sureshbabu K, Nageshwara Rao M, Rambabu C. Forced degradation studies and RP-HPLC method validation for the determination of ceritinib in bulk and its pharmaceutical dosage form. Asian J Pharm Clin Res 2015;8:44-51.

17. Guidance for Industry: Analytical procedures and methods validation for drugs and biologics. US Department of Health and Human Services. Food and Drug Administration. Center for Drug Evaluation and Research, Center for Biologics Evaluation and Research; 2014.

18. International Conference on Harmonization (ICH), Harmonised Tripartite Guideline. Validation of Analytical Procedures: Text and Methodology Q2(R1); 2005.

19. International Conference on Harmonization (ICH), Harmonised Tripartite Guideline. Stability Testing of New Drug Substances and Products Q1A(R2); 2003.

20. Blessy M, Patel RD, Prajapati PN, Agrawal YK. Development of forced degradation and stability indicating studies of drugs-a review. J Pharm Anal 2014;4:159-65.

21. Jayaprakash R, Natesan SK. Stability indicating RP-HPLC method development and validation for the simultaneous determination of vildagliptin and metformin in pharmaceutical dosage form. Int J Pharm Pharm Sci 2017;9:150-7.

22. Deshpande S, Farooqui M, Ganap G, Khadke V, Kayande DD. Development and validation of a gradient HPLC method for quantification of Edetate disodium in lyophilized injectable drug product. Int J Curr Pharm Res 2019;11:38-41.

23. United States Pharmacopeia 40-National Formulary 35:Physical Tests. Chapter 621-Chromatography, System Suitability. Chapter 1225-Validation of Compendial Procedures, USP; 2017.

24. Baje SI, Jyothi B, Madhavi N. RP-HPLC method for simultaneous estimation of ritonavir, ombitasvir and paritaprevir in tablet dosage forms and their stress degradation studies. Int J Appl Pharm 2019;11:193-210. 